\title{
Aplikasi GPS RTK untuk Pemetaan Bidang Tanah
}

\author{
JOKO SETIADY \\ Jurusan Teknik Geodesi, Institut Teknologi Nasional - Bandung \\ Email: Joko_setiady@yahoo.com
}

\begin{abstract}
ABSTRAK
Penggunaan receiver GPS RTK (Real Time Kinematic) pada metode ekstraterestrial untuk penentuan posisi titik saat ini sudah banyak diterapkan. Penelitian ini bertujuan mengkaji sampai sejauh mana ketelitian posisi titik yang diperoleh dari hasil pengukuran secara ekstraterestrial menggunakan GPS RTK untuk pemetaan bidang-bidang tanah berikut kekurangan dan kelebihannya. Dari hasil pengukuran didapat ketelitian rata-rata hasil pengukuran posisi titik menggunakan GPS RTK dibandingkan dengan menggunakan alat ETS (Electronic Total Station) adalah sebesar 0,214 m sehingga dapat diterapkan untuk pembuatan peta skala 1 : 500. Untuk daerah yang terbuka, pengukuran bidang tanah menggunakan GPS RTK memerlukan waktu dua kali lebih cepat dibandingkan dengan ETS. Walaupun GPS RTK mempunyai keunggulan dalam hal efisiensi proses pengukuran di lapangan sehingga dapat mempersingkat waktu pengukuran, akan tetapi memiliki kekurangan dalam hal ketelitian data terutama pada area pengukuran yang tertutup.
\end{abstract}

Kata kunci: GPS RTK, ETS, posisi titik, ekstraterestrial.

\begin{abstract}
The use of RTK GPS receiver (Real Time Kinematic) on extraterrestrial method for point positioning h widely applied. The purpose of this study is to examine the point position accuracy obtained from the measurements using GPS RTK for extraterrestrial mapping plots, including its advantages and disadvantages. Measurement accuracy of the results obtained from the average measurement point positioning using GPS RTK compared using the ETS tool is equal to $0.214 \mathrm{~m}$, so that it can be applied for map making of scale 1: 500. For open areas, field measurements using GPS RTK can be performed by two times faster than using ETS. Although GPS RTK has advantages in terms of measurements process efficiency in the field so as to shorten the time of measurement, but has shortcomings in terms of accuracy of the data, especially in an enclosed area measuring.
\end{abstract}

Keywords: GPS RTK, ETS, point position, extraterrestrial. 


\section{PENDAhUlUAN}

Bidang tanah didefinisikan sebagai bagian permukaan bumi yang merupakan satuan bidang terbatas. Tidak dapat dipungkiri bahwa bidang tanah di permukaan bumi adalah bagian dari ruang yang keberadaannya sangatlah terbatas, untuk itu pemanfaatannya harus dilakukan secara terencana dan terkendali. Pemetaan bidang tanah dilakukan dengan cara melakukan pengukuran posisi titik-titik batas dari bidang tanah untuk mendapatkan kepastian letak bidang tanah tersebut di permukaan Bumi. Pemetaan suatu bidang tanah dilaksanakan dengan cara terestrial, fotogrametris, atau metode lainya.

Saat ini metode penentuan posisi suatu titik di permukaan bumi mengalami kemajuan yang demikian pesat. Hal tersebut ditandai dengan ketersediaan peralatan alat ukur yang dilengkapi dengan teknologi digital terkini. Metode penentuan posisi suatu titik di permukaan bumi dapat dibedakan menjadi dua bagian, yaitu: metode pengukuran secara terestrial dan ekstraterestrial [Abidin, 2000]. Pada pengukuran dengan cara terestrial, penggunaan alat ukur ETS (Elektronic Total Station) saat ini sudah umum digunakan. Sebagaimana diketahui bahwa ETS merupakan gabungan antara alat ukur jarak elektronik dan teodolit berbasis digital sehingga dari pengukuran lapangan didapat koordinat titik - titik dengan ketelitian yang tinggi. Penggunaan receiver GPS RTK (Real Time Kinematic) pada metode ekstraterestrial untuk penentuan posisi titik saat ini sudah banyak digunakan. Hal tersebut disebabkan karena penggunaan metode tersebut memungkinkan untuk mendapatkan posisi titik yang teliti dengan waktu yang singkat. Dalam penelitian ini akan dilakukan kajian penerapan metode ekstraterestrial menggunakan GPS RTK (Real Time Kinematic) untuk pemetaan bidang tanah.

Pengukuran posisi titik-titik dengan metode ekstraterestrial mengunakan receiver GPS RTK saat ini sudah banyak digunakan. Hal tersebut ditunjang oleh kemajuan teknologi sehingga hasil yang diperoleh mempunyai ketelitian yang tinggi dengan waktu yang relatif singkat. Namun perlu dilakukan kajian sampai sejauh mana ketelitian posisi titik yang diperoleh dari hasil pengukuran secara ekstraterestrial menggunakan GPS RTK untuk pemetaan bidang-bidang tanah serta kendalakendala yang dihadapi sehingga dapat diketahui kekurangan dan kelebihannya.

Tujuan dari penelitian ini adalah mengkaji sampai sejauh mana ketelitian posisi titik yang diperoleh dari hasil pengukuran secara ekstraterestrial menggunakan GPS RTK untuk pemetaan bidang-bidang tanah berikut kekurangan dan kelebihannya. Analisis dari hasil penelitian ini didasarkan pada batasan-batasan sebagai berikut: objek pengamatan yang dipilih terdiri dari titik-titik (patok poligon), ruas jalan, dan objek berupa bidang tanah. Data pengukuran posisi titik-titik dilakukan terhadap objek pengamatan dengan metode ekstraterestrial menggunakan receiver GPS RTK (Real Time Kinematic). Data pembanding yang digunakan adalah posisi titik-titik objek pengamatan yang dilakukan dengan metode terestrial menggunakan peralatan ukur ETS (Elektronic Total Station). Peralatan yang digunakan berupa: Perangkat lunak AutoCad Land Desktop 2009, Microsof excel 2007, dan Topcon Link V.5. Peralatan ukur terdiri dari:1 set receiver GPS RTK HI Target V8 V9 dan 1 set ETS GOWIN TKS 202. 


\section{METODOLOGI PENELITIAN}

Metode yang digunakan dalam penelitian ini dapat dilihat pada Gambar 1.

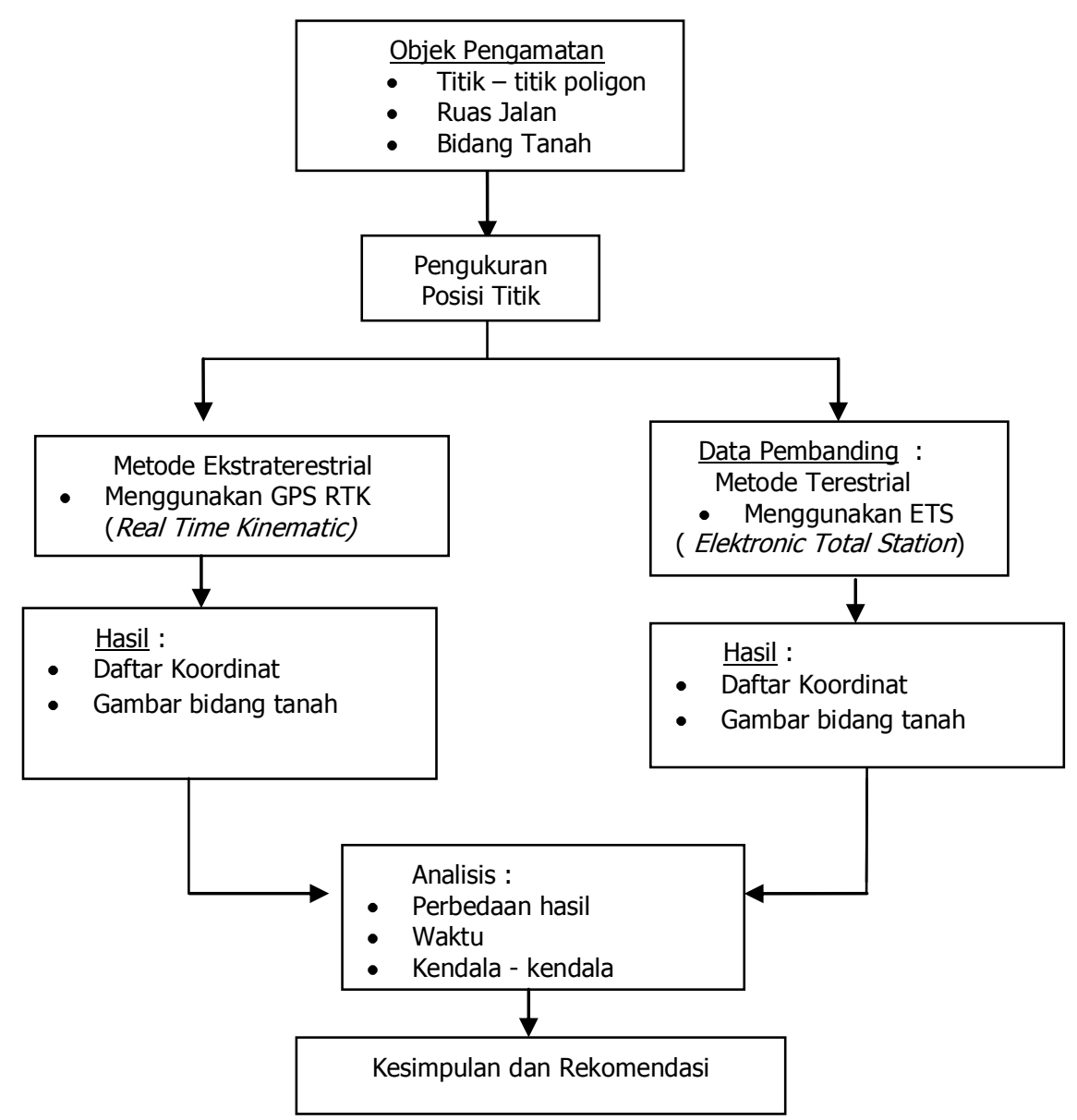

\section{Gambar 1. Metodologi Penelitian}

Bidang tanah merupakan suatu bidang yang dibatasi oleh garis-garis batas yang memisahkan area satu dengan yang lain. Secara ideal seharusnya pengukuran suatu bidang tanah dilakukan dengan mengukur panjang garis-garis batas ataupun dengan mengukur kordinat titik-titik batas yang membentuk bidang tanah tersebut. Dalam penelitian ini pengukuran batas-batas bidang tanah tidak semuanya diukur secara utuh, namun akan diwakili oleh pengukuran titik-titik batas bidang yang terdiri dari : titik-titik yang membentuk poligon, titik-titik batas ruas jalan, dan titiktitik batas bidang tanah. Pengukuran data lapangan dilakukan dengan mengukur posisi titik oleh GPS RTK dan ETS di setiap ruas jalan, titik-titik poligon, dan bidang tanah. Pada pengukuran GPS RTK minimal harus mempunyai minimal 2 receiver, satu receiver digunakan sebagai Base (stasiun receiver) dan receiver yang kedua digunakan untuk Rover. Base secara otomatis mengirim data koreksi melalui radio link ke receiver yang bergerak (rover). Rover yang digunakan untuk mengukur titik yang akan dilakukan penelitian seperti titik poligon, ruas jalan, dan bidang tanah. 
Pengukuran posisi titik secara terestrial dilakukan menggunakan alat ETS dimaksudkan untuk mendapatkan data pembanding koordinat yang diperoleh dari hasil pengukuran.

Tahapan pengolahan data hasil pengukuran diawali dengan proses download data dilakukan pada perangkat Pocket $P C$ ke komputer dengan menggunakan Perangkat Lunak Microsoft Activesync. Microsoft Activesync berfungsi untuk menghubungkan pocket $p c$ dengan komputer menggunakan kabel serial port maka selanjutnya yang harus dilakukan ialah mengaktifkan Activesync dan mengimport point koordinat dari Pocket $P C$ ke komputer dengan menggunakan store point. Proses download data hasil pengukuran ETS ini menggunakan perangkat lunak Topcon Link V.5. Pada prosesnya terdiri dari dua tahap, yaitu: tahap input data/download data ETS dan tahap pengolahan data.

\section{HASIL DAN ANALISIS}

Hasil yang diperoleh dari penelitian ini adalah koordinat titik-titik dari hasil pengukuran secara ekstraterestrial menggunakan receiver GPS RTK dalam sistem koordinat UTM $(x, y, z)$. Sebagai data pembanding digunakan data koordinat hasil pengukuran secara terestris menggunakan alat ukur ETS. Jumlah titik yang diukur oleh GPS RTK sebanyak 14 titik di antaranya 3 titik BM, 10 titik poligon dan 1 BM sebagai nilai titik yang fix (base). Jumlah titik yang diukur oleh GPS RTK ialah sebanyak 20 titik berupa patok jalan dan DGM 5029 (base) sebagai nilai titik yang fix. Letak patok jalan berada pada tepi jalan dipasang berhadapan dengan jarak memanjang antara patok satu dengan yang lainnya bervariasi dengan jarak terkecil sekitar 20 meter. Koordinat titik poligon hasil pengukuran GPS RTK dapat dilihat pada Tabel 1.

Tabel 1. Koordinat Titik Poligon Hasil Pengukuran GPS RTK

\begin{tabular}{|c|c|c|c|c|c|c|c|}
\hline & & \multicolumn{6}{|c|}{ Hasil Ukuran GPS } \\
\hline Alat & Tinjau & $x$ & $y$ & $\mathrm{~h}$ & Solusi & Waktu & Keterangan \\
\hline ITN 01 & & 771827.360 & 9250852.757 & 668.218 & RTKInt & 15menit & Base \\
\hline & itn02 & 771793.070 & 9250869.191 & 663.008 & RTKInt & 2 menit & rover \\
\hline & p.30 & 771762.040 & 9250879.037 & 662.009 & RTKInt & 2 menit & rover \\
\hline & p.20 & 771730.509 & 9250885.376 & 662.858 & RTKInt & 1 menit & rover \\
\hline & p.21 & 771721.728 & 9250906.803 & 661.114 & RTKInt & 2 menit & rover \\
\hline & p.22 & 771681.941 & 9250942.599 & 651.642 & RTKInt & 2 menit & rover \\
\hline & p.10 & 771664.267 & 9250978.660 & 645.052 & RTKInt & 4 menit & rover \\
\hline & p.11 & 771638.441 & 9251003.797 & 640.426 & RTKInt & 3 menit & rover \\
\hline & p.12 & 771626.878 & 9251030.753 & 634.791 & RTKInt & 1 menit & rover \\
\hline & p.13 & 771604.160 & 9251039.361 & 631.060 & RTKInt & 2 menit & rover \\
\hline & p.14 & 771584.326 & 9251059.477 & 628.011 & RTKInt & 1 menit & rover \\
\hline & p.40 & 771566.680 & 9251087.572 & 622.284 & RTKInt & 2 menit & rover \\
\hline & itn3 & 771543.252 & 9251100.873 & 619.542 & RTKInt & 3 menit & rover \\
\hline & itn4 & 771494.343 & 9251158.400 & 617.948 & RTKInt & 2 menit & rover \\
\hline & & & & & $\Sigma$ & 42 menit & \\
\hline
\end{tabular}

Jumlah titik yang diukur oleh GPS RTK ialah sebanyak 90 titik berupa batas bangunan, batas bidang tanah, kolam, dan jalan. Tempat berdiri alat berada di DMG 
5029 (Base) dan P 314 (Base). Waktu pengukuran antara GPS RTK dan ETS dilakukan pada waktu yang sama, akan tetapi proses pengambilan data antara GPS RTK mempunyai waktu yang berbeda.

Analisis ketelitian titik berdasarkan perbedaan data hasil pengukuran menggunakan GPS RTK dengan data hasil pengukuran secara terestris menggunakan ETS, lama waktu pengamatan, dan kendala kendala yang terjadi pada saat pengukuran. Analisis data pada pengukuran poligon menggunakan GPS RTK mempunyai solusi pengukuran yang berbeda dengan tingkat akurasi/ketelitian data yang bervariasi. Solusi pengukuran yang terdapat pada GPS RTK V8.V9 ialah RTK INT, RTD, RTK Float dan Single. RTK INT (Integer Fixed) adalah solusi pengukuran tingkat sentimeter, solusi tersebut didapat bila antena receiver dapat menerima dengan baik sinyal dari satelit serta mendapatkan koreksi data fase dan pseudorange dari stasiun receiver (base), hal ini hampir sama dengan RTD (Real Time Differensial) yang hanya mendapatkan data pseudorange pada realisasinya. RTK Float adalah solusi pengukuran tingkat desimeter, solusi ini didapat karena adanya gangguan visibilitas dalam hal ini sinyal antara antena receiver dengan satelit sehingga tingkat akurasi pengukuran tidak optimal, akan tetapi komunikasi data (frekuensi radio) diterima dengan baik. Single adalah solusi yang didapat bila terdapat gangguan visibilitas (sinyal) antena receiver dengan satelit dan komunikasi data (frekuensi radio) mengalami gangguan atau hilang kontak sehingga tidak ada inisiasi antara base dan rover, hal ini disebabkan karena kondisi area yang sangat tertutup dan tidak terjangkaunya frekuensi radio antara base dan rover.

Solusi pengukuran menggunakan GPS RTK pada titik poligon dari total 14 data semuanya mendapatkan solusi RTK INT (orde sentimeter), pada ruas jalan dari 21 data semuanya mendapatkan solusi RTK INT dan bidang tanah dari total 90 data 20 data RTK Float (orde desimeter), 1 data Single (orde meter), 1 data RTD (orde sentimeter), dan 72 data RTK INT. Pada pengukuran poligon titik-titik poligon dan ruas jalan letaknya berada pada di tepi jalan sehingga kondisi tutupan lahan cukup terbuka sehingga didapatkan solusi receiver RTK INT. Berbeda dengan pengukuran bidang tanah yang kondisi tutupan lahan yang tertutup dalam hal ini terhalang oleh pepohonan sehingga solusi receiver yang didapat sebagian berupa RTK Float bahkan Single.

Analisis proses pengukuran yang dilakukan menggunakan GPS RTK dan menggunakan ETS mempunyai beberapa perbedaan. Pengukuran secara ekstraterestrial menggunakan GPS RTK hanya dilakukan 1 kali setting alat, yaitu yang diaplikasikan pada base selanjutnya rover bergerak mengikuti objek-objek yang akan diukur, dalam hal ini diletakkan pada titik batas bidang tanah. Hal ini dikarenakan pengukuran GPS RTK menggunakan perangkat pemancar dan penerima data, yaitu stasiun receiver (base) mengirimkan data koreksi melalui perangkat radio dengan menggunakan gelombang VHF/UHF sehingga rover mendapatkan koreksi ketelitian hingga akurasi sentimeter bahkan millimeter. Karenanya proses pengukuran tidak perlu saling terlihat, akan tetapi ketelitian data bergantung pada kondisi tutupan lahan dan jangkauan gelombang VHF/UHF, sedangkan pada pengukuran secara terestris menggunakan alat ETS setting alat atau berdiri alat dapat terjadi beberapa kali. Hal ini disebabkan pengukuran secara terestris menggunakan alat ETS yang menggunakan gelombang inframerah sehingga dalam proses pembidikan harus saling terlihat. 
Personel pada pengukuran GPS RTK dapat dilakukan oleh minimal 1 orang, sebab base hanya berada pada titik referensi yang diam dan rover yang dapat langsung bergerak mengikuti objek-objek yang akan diukur. Adapun pada pengukuran menggunakan alat ETS hanya dapat dilakukan minimal oleh 2 orang. Hal ini dikarenakan 1 orang sebagai operator alat (juru ukur) dan 1 orang lainnya sebagai pemegang stik prisma (reflector). Apabila dicermati proses pengukuran menggunakan receiver GPS RTK mempunyai keunggulan dalam hal mobilitas di lapangan sehingga dapat mempersingkat waktu pengukuran, akan tetapi bila kondisi tutupan lahan tertutup maka ketelitian yang dihasilkan tidak optimal dibandingkan dengan pengukuran menggunakan alat ETS.

Perhitungan perbedaan/selisih hasil pengukuran koordinat titik-titik poligon terdapat pada Tabel 2 berikut.

Tabel 2. Perbedaan Koordinat Titik Poligon Hasil Pengukuran GPS RTK dan ETS

\begin{tabular}{|c|c|c|c|c|c|c|c|}
\hline & Selisil & osisi & $d$ & Resultante (m) & dh & Ketelitian Linear & \\
\hline NO & $d x$ & dy & jarak (m) & $\bar{r}=v_{d x^{2}+d y^{2}}$ & (m) & $\mathrm{kl}=1:(r / \mathrm{d})$ & Titik \\
\hline 1 & 0.000 & 0.000 & 0.000 & 0.000 & 0.000 & 0.000 & ITN1 \\
\hline 2 & -0.025 & 0.019 & 38.025 & 0.031 & 0.063 & $1 / 1210.954$ & itn02 \\
\hline 3 & 0.015 & -0.097 & 32.555 & 0.098 & 0.108 & $1 / 716.771$ & p.30 \\
\hline 4 & 0.390 & -0.025 & 32.161 & 0.391 & 0.114 & $1 / 261.571$ & p.20 \\
\hline 5 & -0.170 & 0.009 & 23.157 & 0.171 & 0.042 & $1 / 695.367$ & p.21 \\
\hline 6 & 0.084 & -0.047 & 53.519 & 0.096 & 0.023 & $1 / 1775.841$ & p.22 \\
\hline 7 & -0.087 & 0.066 & 40.159 & 0.109 & 0.089 & $1 / 1890.887$ & p.10 \\
\hline 8 & -0.024 & -0.199 & 36.040 & 0.200 & 0.213 & $1 / 1206.636$ & p.11 \\
\hline 9 & 0.103 & -0.189 & 29.331 & 0.215 & 0.205 & $1 / 1245.546$ & p.12 \\
\hline 10 & -0.082 & 0.331 & 24.294 & 0.341 & 0.230 & $1 / 853.147$ & p.13 \\
\hline 11 & 0.026 & 0.037 & 28.250 & 0.045 & 0.027 & $1 / 7073.384$ & p.14 \\
\hline 12 & 0.014 & 0.007 & 33.177 & 0.016 & 0.050 & $1 / 22414.662$ & p.40 \\
\hline 13 & -0.004 & 0.027 & 26.940 & 0.027 & 0.026 & $1 / 13840.960$ & itn3 \\
\hline 14 & -0.028 & 0.009 & 75.508 & 0.029 & 0.060 & $1 / 15570.445$ & itn4 \\
\hline$\Sigma$ & 0.213 & -0.052 & 473.116 & 1.770 & 1.250 & & \\
\hline -rata & 0.015 & -0.004 & 33.794 & 0.126 & 0.089 & & \\
\hline
\end{tabular}

Resultan (resultante) terkecil adalah 0,016 meter dan resultan terbesar adalah 0,391 meter sehingga nilai rata-rata resultan secara keseluruhan adalah 0,126 meter. Perbedaan beda tinggi terkecil sebesar 0,023 meter dan terbesar 0,230 meter dengan nilai rata-rata beda tinggi sebesar 0,089 meter. Jarak pengukuran terpendek sebesar 23,156 meter dan terjauh sebesar 75,507 meter serta total jumlah jarak pengukuran sebesar 473,115 meter. 

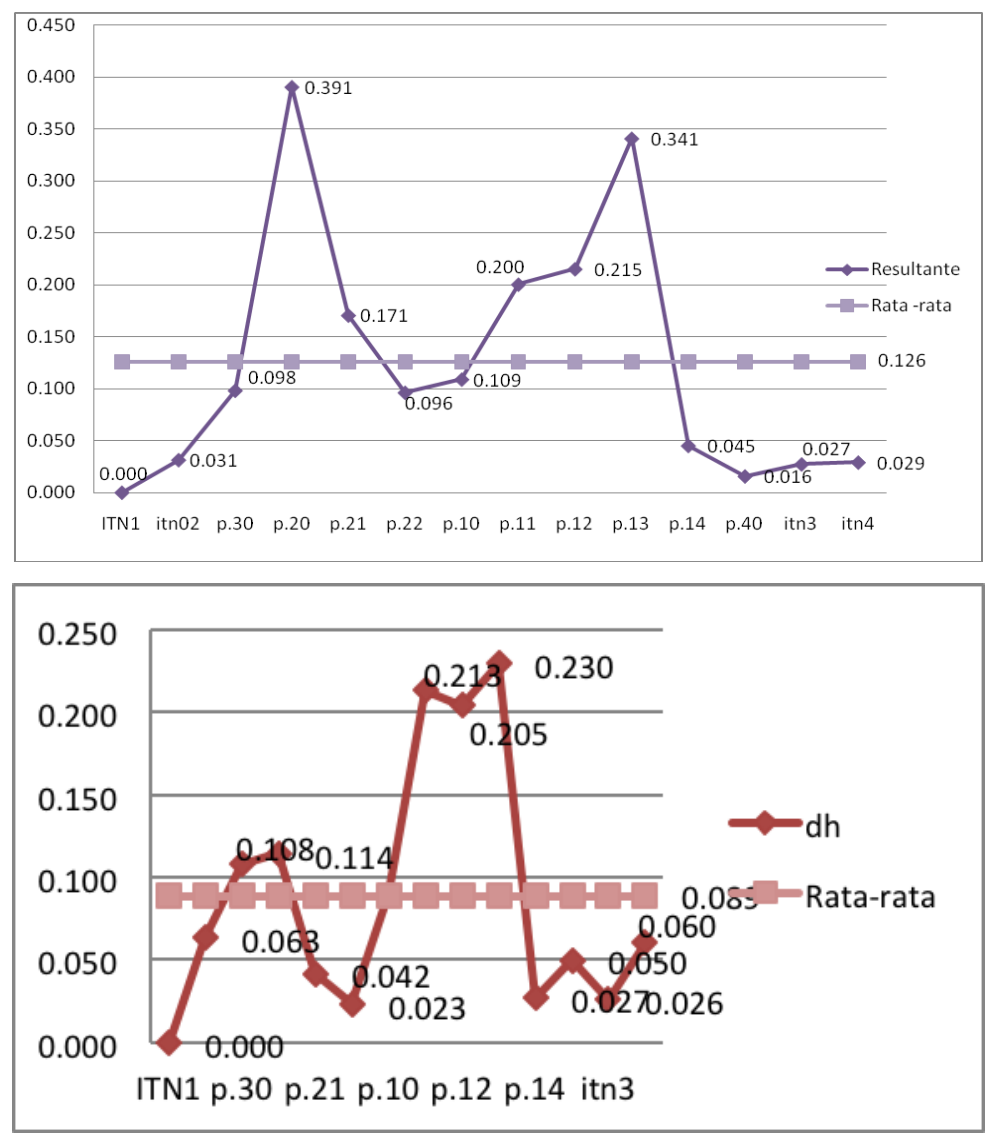

\section{Gambar 2. Perbedaan Posisi Hasil GPS RTK dan ETS pada Poligon}

Pada Gambar 2 terlihat bahwa perbedaan posisi (resultante) terbesar pada titik P.20 dan P.13. Secara grafik menunjukkan perbedaan posisi mengalami perubahan yang signifikan dari titik P.20 sampai P.13. Hal ini disebabkan kondisi pengukuran yang tepat berada di bawah pepohonan sehingga mempengaruhi sinyal satelit yang diterima oleh antena GPS RTK. Perhitungan perbedaan/selisih hasil pengukuran koordinat titik-titik poligon terdapat pada Tabel 3 berikut. Resultante terkecil adalah sebesar 0,012 meter, resultante terbesar sebesar 0,311 meter dan mempunyai nilai rata-rata resultante secara keseleruhan adalah 0,112 meter. Perbedaan beda tinggi terkecil sebesar 0,023 dan terbesar 0,230 dengan rata-rata beda tinggi sebesar 0,130. 
Tabel 3. Perbedaan Koordinat Titik Ruas Jalan Pengukuran GPS RTK dan ETS

\begin{tabular}{|c|c|c|c|c|c|c|}
\hline & \multicolumn{2}{|c|}{ Selisih Posisi } & \multirow{2}{*}{$\frac{d}{\operatorname{jarak}(\mathrm{m})}$} & Resultante(m) & \multirow{2}{*}{$\frac{d h}{(m)}$} & \multirow{2}{*}{$\begin{array}{c}\text { Ketelitian Linear } \\
\mathrm{kl}=1:(\mathrm{r} / \mathrm{d})\end{array}$} \\
\hline NO & $d x$ & dy & & $\bar{r}=v d x^{2}+d y^{2}$ & & \\
\hline 1 & 0.000 & 0.000 & 0.000 & 0.000 & 0.000 & O \\
\hline 2 & 0.039 & -0.024 & 46.328 & 0.046 & 0.235 & $1 / 1007.922$ \\
\hline 3 & -0.020 & 0.037 & 48.623 & 0.042 & 0.193 & $1 / 1159.955$ \\
\hline 4 & 0.109 & -0.103 & 29.041 & 0.150 & 0.096 & $1 / 193.181$ \\
\hline 5 & -0.011 & 0.143 & 31.875 & 0.143 & 0.010 & $1 / 222.247$ \\
\hline 6 & 0.034 & -0.048 & 18.158 & 0.059 & 0.461 & $1 / 308.692$ \\
\hline 7 & 0.009 & 0.134 & 21.156 & 0.134 & 0.050 & $1 / 157.522$ \\
\hline 8 & 0.010 & -0.121 & 29.754 & 0.121 & 0.189 & $1 / 244.977$ \\
\hline 9 & 0.136 & -0.170 & 27.585 & 0.218 & 0.180 & $1 / 126.705$ \\
\hline 10 & 0.205 & 0.234 & 55.518 & 0.311 & 0.256 & $1 / 178.458$ \\
\hline 11 & 0.032 & -0.029 & 62.352 & 0.043 & 0.214 & $1 / 1441.326$ \\
\hline 12 & -0.005 & 0.011 & 75.184 & 0.012 & 0.233 & $1 / 6113.353$ \\
\hline 13 & 0.040 & 0.051 & 72.396 & 0.065 & 0.112 & $1 / 1112.709$ \\
\hline 14 & 0.058 & -0.106 & 156.469 & 0.121 & 0.021 & $1 / 1295.978$ \\
\hline 15 & -0.040 & -0.028 & 156.429 & 0.049 & 0.023 & $1 / 3193.061$ \\
\hline 16 & 0.012 & 0.068 & 172.316 & 0.069 & 0.046 & $1 / 2492.302$ \\
\hline 17 & 0.019 & 0.030 & 174.737 & 0.035 & 0.068 & $1 / 4957.712$ \\
\hline 18 & 0.172 & -0.105 & 294.556 & 0.201 & 0.040 & $1 / 1463.553$ \\
\hline 19 & 0.132 & 0.198 & 293.389 & 0.238 & 0.020 & $1 / 1232.901$ \\
\hline 20 & 0.198 & -0.023 & 314.164 & 0.199 & 0.064 & $1 / 1576.874$ \\
\hline 21 & 0.027 & 0.095 & 313.547 & 0.099 & 0.090 & $1 / 3174.767$ \\
\hline$\Sigma$ & 0.570 & 0.073 & & 2.357 & 2.601 & \\
\hline rata & 0.041 & 0.005 & & 0.112 & 0.130 & \\
\hline
\end{tabular}

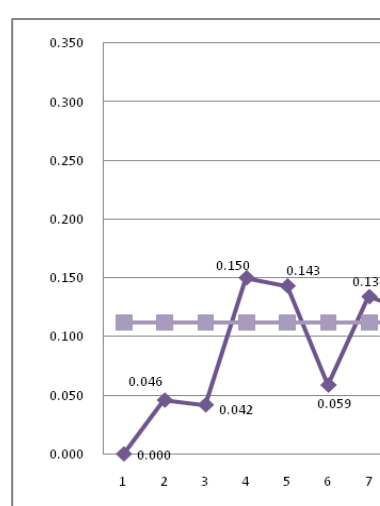

\section{Gambar 3 Perbedaan Posisi Hasil GPS RTK dan ETS pada Ruas Jalan}

Pada Gambar 3 terlihat bahwa perbedaan posisi (resultan) terbesar pada Patok Jalan 10 dan 19. Secara grafik menunjukkan perbedaan posisi mengalami perubahan yang signifikan dari pada Patok Jalan 7 sampai 10 dan Patok Jalan 18 sampai 21. Hal ini disebabkan kondisi pengukuran yang tepat berada di bawah pepohonan sehingga mempengaruhi sinyal satelit yan diterima oleh antena GPS RTK. Akan tetapi, pada beda tinggi titik perbedaan yang terbesar terjadi pada Patok jalan 6 dan 10 seperti yang dapat dilihat pada Gambar 4. Pada Tabel 5 terlihat bahwa resultan terkecil adalah 0,016 meter dan terbesar pada perbedaan hasil pengukuran bidang tanah adalah 1,607 meter sehingga nilai rata-rata resultan secara keseluruhan adalah 0,423 meter. Perbedaan beda tinggi terkecil sebesar 0,002 meter dan terbesar 2,338 meter. Pada Gambar 5 terlihat bahwa perbedaan posisi (resultan) terbesar pada Titik 53. 


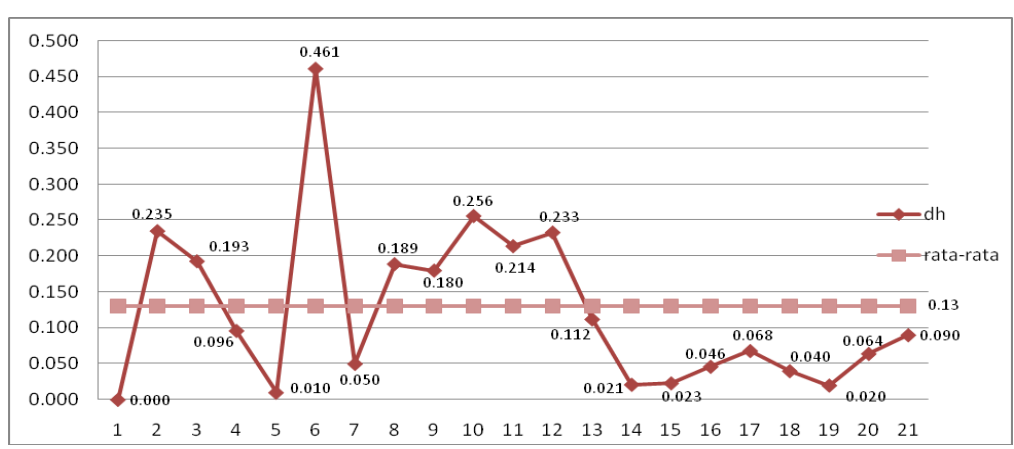

Gambar 4. Perbedaan Beda Tinggi Hasil GPS RTK dan ETS pada Ruas jalan

Tabel 5. Perbedaan Koordinat Titik Bidang Tanah Pengukuran GPS RTK dan ETS

\begin{tabular}{|c|c|c|c|c|c|c|c|c|}
\hline & \multicolumn{2}{|c|}{ Selisih Posisi } & \multirow{2}{*}{$\frac{d}{\operatorname{darak}(\mathrm{m})}$} & \multicolumn{2}{|c|}{ Resultante (m) } & \multirow{2}{*}{$\frac{\mathrm{dh}}{(\mathrm{m})}$} & \multirow{2}{*}{$\begin{array}{c}\text { Ketelitian Linear } \\
\mathrm{kl}=1:(\bar{r} / \mathrm{d})\end{array}$} & \multirow[b]{2}{*}{ Titik } \\
\hline $\mathrm{NO}$ & $\mathrm{dx}$ & dy & & $\bar{r}$ & $=\sqrt{d} x^{2}+d y^{2}$ & & & \\
\hline 1 & 0.000 & 0.000 & 0.000 & & 0.000 & 0.000 & 0.000 & P.3.14 \\
\hline 2 & 0.444 & -0.036 & 6.058 & & 0.446 & 0.002 & $1 / 13.594$ & bts \\
\hline 3 & 0.348 & 0.006 & 2.123 & & 0.348 & 0.048 & $1 / 6.106$ & bts1 \\
\hline 4 & 0.399 & 0.115 & 8.387 & & 0.415 & 0.019 & $1 / 20.201$ & bts2 \\
\hline 5 & 0.434 & -0.089 & 19.351 & & 0.443 & 0.036 & $1 / 43.659$ & bts3 \\
\hline 6 & 0.143 & 0.152 & 24.694 & & 0.209 & 0.201 & $1 / 118.404$ & bts4 \\
\hline 7 & 0.388 & -0.177 & 28.508 & & 0.427 & 0.005 & $1 / 66.833$ & bts5 \\
\hline 8 & 0.404 & -0.062 & 29.545 & & 0.409 & 0.000 & $1 / 72.319$ & bts6 \\
\hline 9 & 0.518 & 0.089 & 32.315 & & 0.525 & 0.100 & $1 / 61.528$ & bts7 \\
\hline 10 & 0.662 & 0.130 & 32.726 & & 0.674 & 0.004 & $1 / 48.536$ & bts8 \\
\hline 11 & 0.651 & 0.616 & 34.742 & & 0.896 & 0.160 & $1 / 38.769$ & bts9 \\
\hline 12 & 0.528 & -0.096 & 37.193 & & 0.537 & 0.071 & $1 / 69.253$ & bts10 \\
\hline 13 & 0.556 & 0.357 & 37.696 & & 0.661 & 0.083 & $1 / 57.05$ & bts11 \\
\hline 14 & 0.339 & -0.123 & 38.253 & & 0.361 & 0.050 & $1 / 106.0199$ & bts12 \\
\hline 15 & 0.632 & 0.126 & 43.392 & & 0.645 & 0.041 & $1 / 67.322$ & bts13 \\
\hline 16 & 0.522 & -0.059 & 45.968 & & 0.525 & 0.038 & $1 / 87.553$ & bts14 \\
\hline 17 & 0.540 & -0.081 & 48.692 & & 0.546 & 0.024 & $1 / 89.204$ & bts15 \\
\hline 18 & 0.459 & 0.053 & 54.300 & & 0.462 & 0.027 & $1 / 117.469$ & bts16 \\
\hline 19 & 0.612 & -0.188 & 55.989 & & 0.640 & 0.010 & $1 / 87.517$ & bts17 \\
\hline 20 & 0.530 & -0.467 & 56.607 & & 0.707 & 0.158 & $1 / 80.092$ & bts18 \\
\hline$\Sigma$ & -1.346 & 5.646 & & & 38.110 & 20.042 & & \\
\hline & -0.014 & 0.060 & & $\bar{r}$ & 0.423 & 0.219 & & \\
\hline
\end{tabular}

Secara grafik seperti yang ditunjukkan pada Gambar 5, perbedaan posisi mengalami perubahan yang signifikan dari Titik 40 sampai 58. Hal ini disebabkan karena kondisi pengukuran yang tepat berada di bawah pepohonan dan pojok bangunan yang tertutup sehingga mempengaruhi sinyal satelit yang diterima oleh antena GPS RTK. Berbeda dengan Titik 1 sampai 34 yang berupa batas bidang tanah yang berlokasi di persawahan yang mempunyai perbedaan yang relatif kecil. Perbedaan beda tinggi titik mengalami hal serupa dengan perbedaan posisi titik, jika dilihat pada Gambar 6 perbedaan posisi mengalami perubahan yang signifikan dari Titik 40 sampai 60 . 


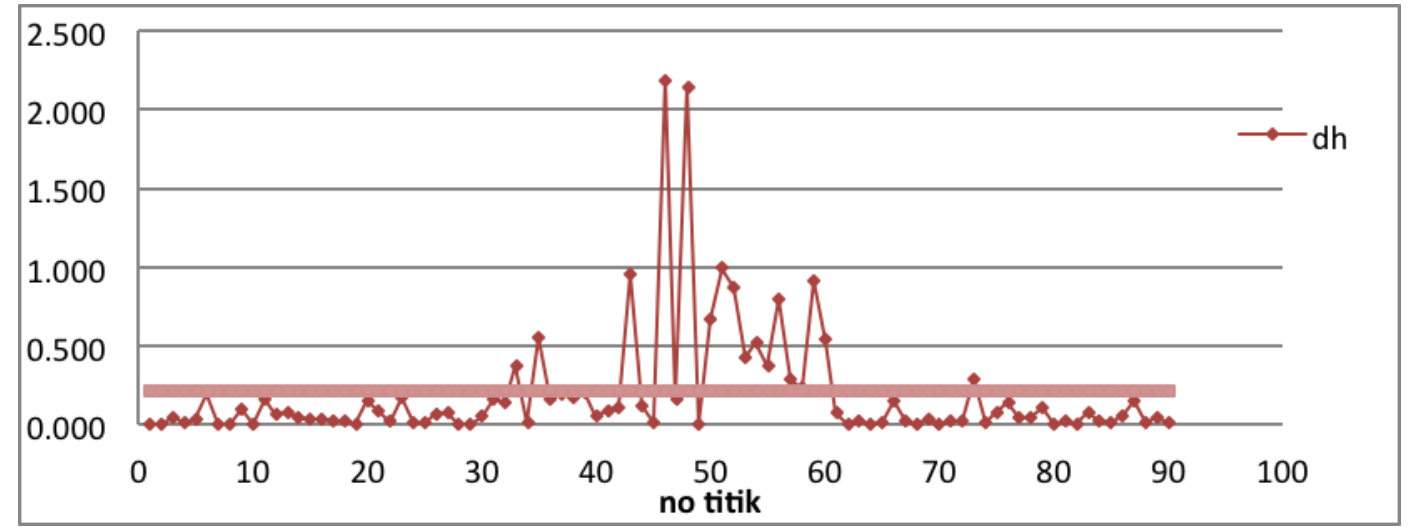

Gambar 5. Perbedaan posisi hasil GPS RTK dan ETS pada Bidang Tanah

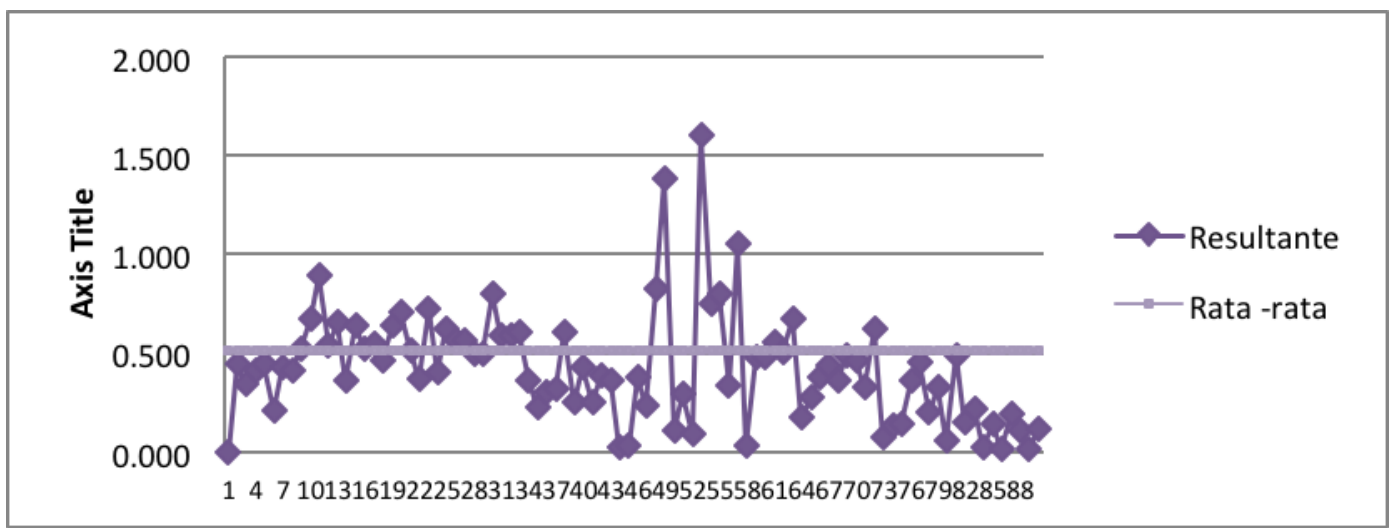

\section{Gambar 6. Perbedaan Beda Tinggi GPS RTK dan ETS pada Bidang Tanah}

Kendala-kendala yang dihadapi pada waktu pengukuran menggunakan receiver GPS RTK di lapangan adalah kondisi tutupan lahan pengukuran yang relatif tertutup sehingga menyulitkan receiver GPS RTK untuk menemukan solusi yang terbaik yang berakibat pada bertambahnya waktu pengukuran, sehingga lama waktu pengukuran GPS RTK di setiap titik dapat mempengaruhi hasil ketelitian yang diperoleh.

Pada pengukuran titik poligon menggunakan receiver GPS RTK memerlukan waktu kira-kira 15 menit untuk proses setting base sedangkan pada penentuan titik menggunakan rover memerlukan waktu antara 1-4 menit hal ini bergantung pada jarak antar titik di lapangan dan kondisi tutupan lahan di lapangan, sedangkan pada alat ETS kira-kira memerlukan waktu 15 menit untuk persiapan sentring dan setting station pengukuran dan proses pembidikan memerlukan waktu 30 detik - 1 menit.

Waktu yang digunakan dalam pengukuran poligon menggunakan GPS RTK adalah 42 menit dengan jarak antara base dan titik terakhir yaitu sejauh 452,015 meter, sedangkan pada pengukuran menggunakan alat ETS memerlukan waktu 204 menit (3 jam 24 menit). Pada pengukuran ruas jalan total waktu yang digunakan GPS RTK adalah 62 menit (1 jam 2 menit), sedangkan pada pengukuran menggunakan alat ETS total waktu yang digunakan adalah 84 menit. Pada pengukuran bidang tanah menggunakan GPS RTK memerlukan waktu 178 menit, sedangkan menggunakan alat ETS memerlukan waktu 190 menit. 


\section{KESIMPULAN}

Ketelitian rata-rata hasil pengukuran posisi titik secara ekstraterestrial menggunakan GPS RTK dibandingkan terhadap hasil pengukuran posisi titik secara terestris menggunakan alat ETS adalah sebesar 0,214 $\mathrm{m}$. Bila ketelitian pengeplotan sebesar $\pm 0.5 \mathrm{~mm}$, maka pengukuran posisi titik secara ekstraterestrial menggunakan GPS RTK dapat diterapkan untuk pembuatan peta skala 1 : 500. Perbedaan rata-rata hasil pengukuran luas bidang tanah menggunakan GPS RTK dibandingkan terhadap hasil pengukuran batas bidang tanah menggunakan ETS adalah $2,579 \%$, bila toleransi ketelitian pengukuran luas bidang tanah diambil $\pm 2 \%$ (standard BPN) maka pengukuran bidang tanah menggunakan GPS RTK dapat diterapkan. Untuk daerah yang terbuka pada pengukuran bidang tanah menggunakan GPS RTK memerlukan waktu dua kali lebih cepat dibandingkan dengan ETS. Walaupun GPS RTK mempunyai keunggulan dalam hal efisiensi proses pengukuran di lapangan sehingga dapat mempersingkat waktu pengukuran, akan tetapi memiliki kekurangan dalam hal ketelitian data terutama pada area pengukuran yang tertutup. Pada pemetaan skala besar, bila penentuan posisi objek bidang tanah menggunakan receiver GPS RTK sebaiknya area pengukuran berada pada kondisi yang terbuka. Pemasangan Base sebaiknya dipasang ditempat yang relatif terbuka. Hal ini disebabkan diperlukannya visibilitas yang baik antara satelit dengan receiver dan komunikasi radio antara base dan rover. Untuk memaksimalkan faktor visibilitas antara base dan rover, maka antena radio komunikasi dipasang setinggi mungkin ( \pm 2.5 meter).

\section{UCAPAN TERIMA KASIH}

Penulis mengucapkan terima kasih kepada PT Mysurv Penta Benua yang telah menyediakan peralatan GPS untuk keperluan penelitian ini.

\section{DAFTAR PUSTAKA}

Abidin, H.Z. 2000. Penentuan Posisi Dengan GPS dan Aplikasinya. Jakarta: P.T. Pradnya Paramita. Edisi Kedua. ISBN 979-408-377-1.268 pp. 